\title{
Shewanella psychrophila sp. nov. and Shewanella piezotolerans sp. nov., isolated from west Pacific deep-sea sediment
}

\author{
Xiang Xiao, ${ }^{1}$ Peng Wang, ${ }^{1,2}$ Xiang Zeng, ${ }^{1}$ Douglas Hoyt Bartlett ${ }^{3}$ \\ and Fengping Wang ${ }^{1}$ \\ ${ }^{1}$ Key Laboratory of Marine Biogenetic Resources, Third Institute of Oceanography, State \\ Oceanic Administration, Xiamen, 361005, P. R. China \\ ${ }^{2}$ State Key Laboratory of Marine Geology, Tongji University, Shanghai, P. R. China \\ ${ }^{3}$ Center for Marine Biotechnology and Biomedicine, Marine Biology Research Division, Scripps \\ Institution of Oceanography, University of California, San Diego, La Jolla, CA 92093-0202, \\ USA
}

Correspondence

Fengping Wang

fengpingw@yahoo.com

Two Shewanella-like bacterial strains, $\mathrm{WP}^{\top}$ and $\mathrm{WP}^{\top}{ }^{\top}$, which were isolated from west Pacific deep-sea sediment, were studied to determine their taxonomic position. Cells of the two bacteria were facultatively anaerobic, Gram-negative rods and motile by means of a single polar flagellum. Strain WP2 ${ }^{\top}$ was psychrophilic, growing optimally at about $10-15^{\circ} \mathrm{C}$, whereas strain WP3 ${ }^{\top}$ was psychrotolerant, growing optimally at $15-20^{\circ} \mathrm{C}$. The two strains grew in the pressure range 0.1-50 MPa, with optimal growth at $20 \mathrm{MPa}$. Strain $\mathrm{WP}^{\top}$ was able to use nitrate, fumarate, trimethylamine $\mathrm{N}$-oxide (TMAO), DMSO and insoluble Fe(III) as terminal electron acceptors during anaerobic growth, whereas strain $\mathrm{WP}^{\top}$ was able to use only nitrate, TMAO and DMSO. The 16S rRNA gene sequences of strains $\mathrm{WP}^{\top}$ and $\mathrm{WP}^{\top}$ were $97 \%$ identical, and showed highest similarity (97\%) to those of Shewanella fidelis KMM 3589 and Shewanella benthica ATCC $43992^{\top}$, respectively. The gyrB gene sequences of strains $\mathrm{WP} 2^{\top}$ and $\mathrm{WP} 3^{\top}$ were also determined, and showed highest similarity to those of Shewanella violacea JCM $10179^{\top}(90 \%)$ and Shewanella sairae SM2-1 ${ }^{\top}(87 \%)$, respectively. Contrary to the $16 \mathrm{~S}$ rRNA gene sequence results, the phylogeny based on gyrB gene sequence analysis placed strain WP2 ${ }^{\top}, S$. violacea and $S$. benthica in one group, while strain $\mathrm{WP}^{\top}$ grouped with $S$. fidelis and $S$. sairae. DNA-DNA hybridization experiments supported the placement of strain $\mathrm{WP}^{\top}{ }^{\top}$ with $S$. violacea and $S$. benthica. Phylogenetic evidence, together with DNA-DNA relatedness and phenotypic characteristics, indicated that the two new strains represented two novel deep-sea Shewanella species. The names Shewanella psychrophila sp. nov. (type strain $\mathrm{WP}^{\top}=\mathrm{JCM} 13876^{\top}=\mathrm{CGMCC}^{\top} .6159^{\top}$ ) and Shewanella piezotolerans (type strain $\mathrm{WP}^{\top}=\mathrm{JCM} 13877^{\top}=\mathrm{CGMCC} 1.6160^{\top}$ ) are proposed.

Shewanella species are widely distributed in nature, especially associated with aquatic and marine environments (MacDonell \& Colwell, 1985; Skerratt et al., 2002; Venkateswaran et al., 1998, 1999; Satomi et al., 2003). At the time of writing the genus comprises more than 20 recognized species, among which Shewanella benthica, Shewanella violacea and Shewanella profunda have been isolated from deep-sea environments (Deming et al., 1984; MacDonell \& Colwell, 1985; Nogi et al., 1998; Toffin et al.,

Abbreviations: EPA, eicosapentanoic acid; TMAO, trimethylamine $\mathrm{N}$-oxide. The GenBank/EMBL/DDBJ accession numbers for the 16S rRNA and gyrB gene sequences of Shewanella psychrophila WP2 ${ }^{\top}$ are AJ551089 and AM229307, and those of Shewanella piezotolerans WP3 $^{\top}$ are AJ551090 and AM229308, respectively.
2004). Kato \& Nogi (2001) divided the genus Shewanella into two major branches, groups 1 and 2. Most Shewanella group 1 species are psychrophilic/psychrotolerant and piezophilic/piezotolerant and produce eicosapentanoic acid (EPA); by contrast, species in group 2 are mesophilic, pressure-sensitive and produce no or only trace amounts of EPA. Shewanella group 1 species include $S$. benthica, $S$. violacea, S. hanedai, S. gelidimarina and S. pealeana; Shewanella group 2 species include $S$. putrefaciens, $S$. oneidensis, S. algae, S. baltica, S. amazonensis and $S$. frigidimarina.

Shewanella strains are the most abundant Proteobacteria in the deep sea (Kato \& Nogi, 2001; Kato, 1999). We have previously reported the isolation of two psychrotolerant/ psychrophilic Shewanella strains, designated $\mathrm{WP}^{\mathrm{T}}$ and 
$\mathrm{WP} 3^{\mathrm{T}}$, from a deep-sea sediment (Wang et al., 2004). In the present study, these two strains were further characterized based on combined phenotypic, phylogenetic and chemotaxonomic analyses. They were determined to represent two novel deep-sea Shewanella species.

Strains $\mathrm{WP}^{\mathrm{T}}$ and $\mathrm{WP}^{\mathrm{T}}$ were isolated from west Pacific deep-sea sediment $\left(142^{\circ} 30^{\prime} 08^{\prime \prime} \mathrm{E} 8^{\circ} 00^{\prime} 11^{\prime \prime} \mathrm{N}\right)$ at a depth of $1914 \mathrm{~m}$. The reference strain Shewanella fidelis LMG 20551 ${ }^{\mathrm{T}}$ was obtained from the Belgian Co-ordinated Collections of Microorganisms (BCCM/LMG), S. benthica ATCC $43992^{\mathrm{T}}$ from the American Type Culture Collection (ATCC) and $S$. violacea JCM $10179^{\mathrm{T}}$ from the Japan Collection of Microorganisms (JCM). These bacteria were grown in marine $2216 \mathrm{E}$ medium $(0.5 \%$ tryptone, $0.1 \%$ yeast extract, $3.4 \% \mathrm{NaCl}$ and $\left.0.01 \% \mathrm{FePO}_{4}, \mathrm{pH} 7.6-7.8\right)$. Strain $\mathrm{WP}^{\mathrm{T}}$ was grown at $15^{\circ} \mathrm{C}$, strain WP3 $3^{\mathrm{T}}$ at $20^{\circ} \mathrm{C}$, S. benthica and $S$. violacea at $10^{\circ} \mathrm{C}$, and $\mathrm{S}$. fidelis at $25^{\circ} \mathrm{C}$ unless otherwise indicated. High-pressure cultivation was performed using a hand-operated pump and a quick-fit connector to the highpressure vessels (Yayanos \& Dietz, 1982; Li et al., 2006). Marine 2216E medium was inoculated with $1 \%$ inoculum culture in exponential growth phase; $60 \mathrm{ml}$ of inoculated medium was dispersed in sterile injection syringes. Duplicate syringes were placed into the high-pressure vessels and pressurized. Growth of the cultures was checked by decompressing the vessels and was monitored by measuring the optical absorption at $\mathrm{OD}_{600}$. Growth tests at different pressures were repeated three times.

Morphological, biochemical and physiological tests followed the general procedures described by Dong \& Cai (2001). The ability of the strains to utilize a broad range of carbon sources was determined by using Biolog GN2 microplates. Cell morphology of the bacteria was observed by using light and transmission electron microscopy. After around 6-7 days incubation on marine 2216E agar plates at $10^{\circ} \mathrm{C}$, the two new strains formed pale-yellow colonies of $0.5 \mathrm{~mm}$ in diameter with rounded edges. After 5 days incubation in marine $2216 \mathrm{E}$ broth, the cell aggregates showed a pinkish colour. Cells of strains $\mathrm{WP}^{\mathrm{T}}$ and $\mathrm{WP}^{\mathrm{T}}$ were Gram-negative rods, $0.5-0.8 \mu \mathrm{m}$ wide and $2-5 \mu \mathrm{m}$ long, and motile by means of a single polar flagellum (Fig. 1). When incubated in liquid culture, strain $\mathrm{WP}^{\mathrm{T}}$ grew over a temperature range of $0-20{ }^{\circ} \mathrm{C}$, and optimally at $10-15^{\circ} \mathrm{C}$; strain $\mathrm{WP} 3^{\mathrm{T}}$ was able to grow at $0-28^{\circ} \mathrm{C}$, with optimal growth at $15-20^{\circ} \mathrm{C}$. The strains were also cultivated in $2216 \mathrm{E}$ media modified with the addition of $\mathrm{NaCl}$ $(0-12 \%)$. The two new strains required $\mathrm{NaCl}$ for growth. They were able to grow at salinities of $1-7.2 \%$, with optimum growth at 3-4\% NaCl . The strains were tested for their ability to grow at pressures of $0.1,10,20,30,40$ and $50 \mathrm{MPa}$. Strains $\mathrm{WP}^{\mathrm{T}}{ }^{\mathrm{T}}$ and $\mathrm{WP}^{\mathrm{T}}$ showed growth within the pressure range 0.1-50 MPa and displayed optimal growth at $20 \mathrm{MPa}$ (Fig. 2).

Strain $\mathrm{WP}^{\mathrm{T}}$ was able to use citrate, maltose, $\mathrm{N}$-acetyl-Dglucosamine, sucrose and D-trehalose as sole carbon sources. Nitrate was reduced to nitrite. Hydrogen sulfide was not
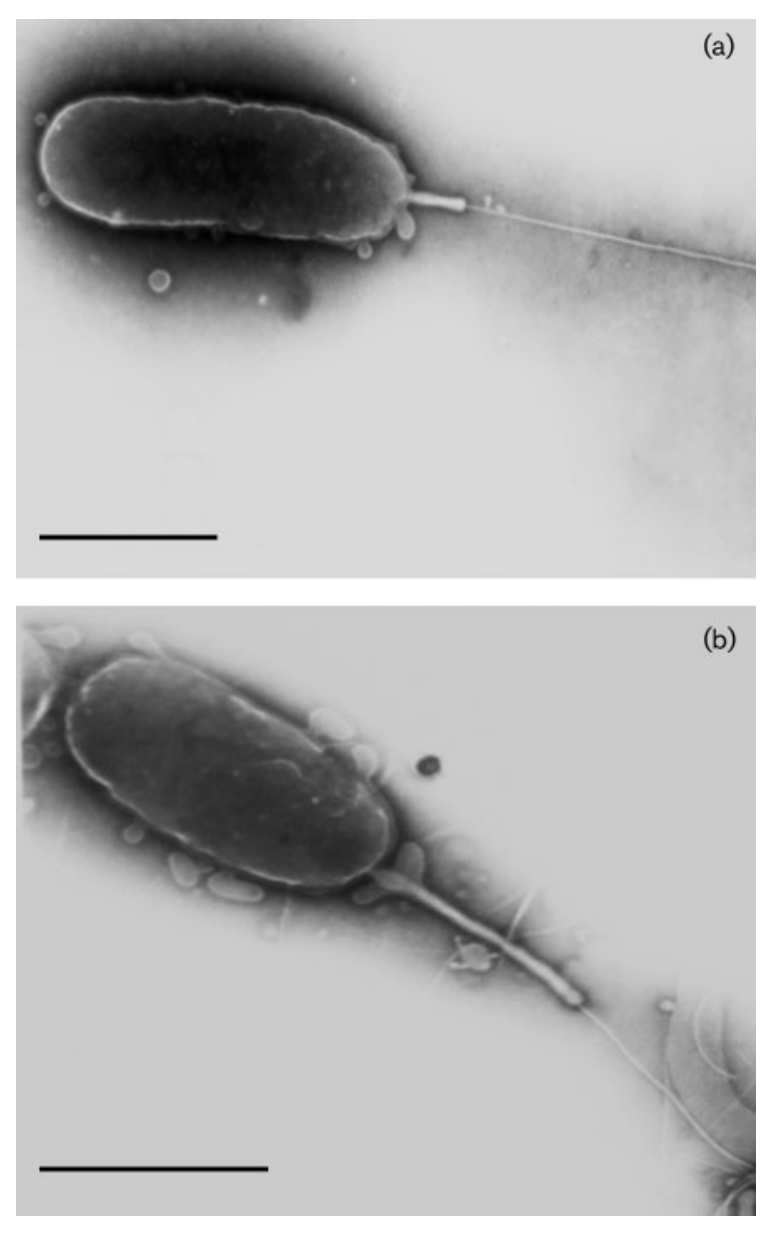

Fig. 1. Transmission electron micrographs of cells of strain $\mathrm{WP}^{\top}$ (a) and $\mathrm{WP}^{\top}$ (b). Cells were grown on $2216 \mathrm{E}$ agar plates at $15^{\circ} \mathrm{C}$ for $16 \mathrm{~h}$. One colony was picked and dispersed in $100 \mu \mathrm{l}$ PBS buffer, and $5 \mu \mathrm{l}$ liquid was placed on a copper grid for negative staining using $1 \%$ uranyl acetate. Bars, $0.5 \mu \mathrm{m}$.

produced. Strain $\mathrm{WP} 2^{\mathrm{T}}$ was positive for cytochrome oxidase and catalase, and negative for the production of lipase, gelatinase, chitinase and amylase (Table 1). Strain WP3 ${ }^{\mathrm{T}}$ used acetate, D-glucose, maltose and $\mathrm{N}$-acetyl-D-glucosamine as sole carbon sources. Nitrate was reduced to nitrite. Hydrogen sulfide was produced. Strain $\mathrm{WP}^{\mathrm{T}}$ was positive for cytochrome oxidase, lipase, gelatinase, amylase and catalase, but negative for the production of chitinase (Table 1).

Dissimilatory iron reduction was tested using lactate as the carbon and energy source (Bozal et al., 2002). Anaerobic growth was also evaluated using trimethylamine $\mathrm{N}$-oxide (TMAO), DMSO, sodium fumarate, sodium nitrite and sodium nitrate in the same medium in which Fe(III) citrate was omitted. Strain $\mathrm{WP}^{\mathrm{T}}$ was able to utilize nitrate, fumarate, TMAO, DMSO and insoluble Fe(III) as terminal electron acceptors for anaerobic growth, whereas strain $\mathrm{WP} 2^{\mathrm{T}}$ used only nitrate, TMAO and DMSO. 


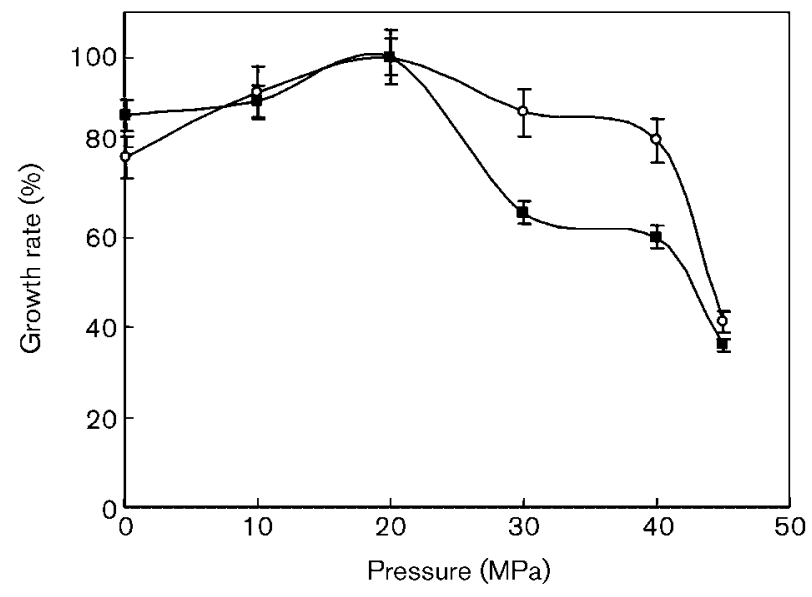

Fig. 2. Growth of strains $W P 2^{\top}(\bigcirc)$ and $W P 3^{\top}(\boldsymbol{\square})$ at different pressures (at $15^{\circ} \mathrm{C}$ ). For strain WP2 ${ }^{\top}, 100 \%$ growth rate: $1 / t_{\mathrm{d}}$ $=0.405$; for strain $\mathrm{WP}^{\top}, 100 \%$ growth rate: $1 / t_{\mathrm{d}}=0.5$, where $t_{\mathrm{d}}$ is doubling time. Bars indicate SD of three experiments.

Strains $\mathrm{WP}^{\mathrm{T}}$ and $\mathrm{WP} 3^{\mathrm{T}}$ were grown in $250 \mathrm{ml}$ marine $2216 \mathrm{E}$ broth. Cultures were incubated with shaking at 150 r.p.m. for 24 h. The cell membrane was extracted via the TCA method and purified with trypsin according to Schleifer \& Kandler (1972). Isoprenoid quinones were extracted and purified according to Collins et al. (1977). The

Table 1. Phenotypic characteristics of strains $W P 2^{\top}$ and $\mathrm{WP3}^{\top}$ and related Shewanella species

Taxa: 1, strain $\mathrm{WP}^{\mathrm{T}} ; 2$, strain $\mathrm{WP}^{\mathrm{T}} ; 3$, S. benthica ATCC $43992^{\mathrm{T}}$; 4, S. violacea JCM $10179^{\mathrm{T}}$; 5, S. fidelis LMG $20551^{\mathrm{T}}$. +, Positive reaction; -, negative reaction; V, variable reaction; ND, not determined. All are positive for catalase and oxidase.

\begin{tabular}{|lccccc|}
\hline Characteristic & $\mathbf{1}$ & $\mathbf{2}$ & $\mathbf{3}$ & $\mathbf{4}$ & $\mathbf{5}$ \\
\hline Optimal growth & $10-15$ & $15-20$ & $4-15$ & 8 & $20-25$ \\
temperature $\left({ }^{\circ} \mathrm{C}\right)$ & & & & & \\
DNA G $+\mathrm{C}$ content $(\mathrm{mol} \%)$ & 51 & 49 & 48 & 47 & 45 \\
Production of $\mathrm{H}_{2} \mathrm{~S}$ & - & + & + & - & + \\
Gelatinase & - & + & + & + & + \\
Chitinase & - & - & $\mathrm{ND}$ & $\mathrm{ND}$ & - \\
Amylase & - & + & - & - & - \\
Lipase & - & + & $\mathrm{ND}$ & $\mathrm{ND}$ & $\mathrm{V}$ \\
Use as sole carbon sources: & & & & & \\
Acetate & - & + & $\mathrm{ND}$ & $\mathrm{ND}$ & $\mathrm{ND}$ \\
Cellobiose & - & - & + & + & $\mathrm{ND}$ \\
Citrate & + & - & $\mathrm{ND}$ & $\mathrm{ND}$ & - \\
D-Galactose & - & - & - & + & - \\
D-Glucose & - & + & + & + & + \\
Maltose & + & + & - & - & $\mathrm{ND}$ \\
$N$-acetyl-D-glucosamine & + & + & $\mathrm{ND}$ & $\mathrm{ND}$ & $\mathrm{ND}$ \\
Sucrose & + & - & - & - & - \\
D-Trehalose & + & - & - & - & $\mathrm{ND}$ \\
\hline
\end{tabular}

purified menaquinones were analysed by HPLC-MS (LCQ MAT; Finnigan) (Nishijima et al., 1997) with an APCI (atmospheric pressure chemical ionization) ion source using a solution of 2-propanol and acetonitrile (1.25:1, v/v). Ubiquinones and menaquinones were found in the two new strains. The major ubiquinones in strains $\mathrm{WP} 2^{\mathrm{T}}$ and $\mathrm{WP} 3^{\mathrm{T}}$ were ubiquinone 7 (Q7) (59 and $60 \%$, respectively) and ubiquinone 8 (Q8) (41 and $40 \%$, respectively). Traces of menaquinone 7 (MK7) and monomethylmenaquinone 7 (MMK7) were also detected.

Cells for cellular fatty acid analysis were likewise harvested after cultivation for $24 \mathrm{~h}$. Fatty acids were extracted and analysed following the instructions of the Microbial Identification System operating manual (MIDI Inc.). The fatty acid profiles of strains $\mathrm{WP} 2^{\mathrm{T}}$ and $\mathrm{WP} 3^{\mathrm{T}}$ were typical of members of the genus Shewanella and included iso-13:0, $14: 0$, iso-15:0,16:0,16:1, 18:1 and 20:5 (Table 2).

Genomic DNA was extracted as described by Chen et al. (2005). The $\mathrm{G}+\mathrm{C}$ content of the DNA was determined using HPLC analysis of hydrolysed DNA according to Tamaoka \& Komagata (1984). The obtained nucleoside mixture was then separated by reversed-phase HPLC using a $\mathrm{C}_{18}$ column (Kromasil ODS, $5 \mu \mathrm{m}, 250 \times 4.6 \mathrm{~mm}$ inner diameter) at room temperature. The solvent was $0.05 \mathrm{~mol} \mathrm{l}^{-1} \mathrm{NH}_{4} \mathrm{H}_{2} \mathrm{PO}_{4}, \mathrm{pH} 4.0$, with $7 \%$ acetonitrile (Tamaoka \& Komagata, 1984). The $\mathrm{G}+\mathrm{C}$ content was calculated based on determination of the $\mathrm{G} /(\mathrm{G}+\mathrm{T})$ content according to Mesbah et al. (1989). The DNA G $+C$ content of strains $\mathrm{WP}^{\mathrm{T}}$ and $\mathrm{WP}^{\mathrm{T}}$ was 51 and $49 \mathrm{~mol} \%$, respectively.

Table 2. Fatty acid composition (\%) of strains $W P 2^{\top}$ and $\mathrm{WP3}^{\mathrm{T}}$

Strain $\mathrm{WP} 2^{\mathrm{T}}$ was grown at $10^{\circ} \mathrm{C}$ and strain $\mathrm{WP} 3^{\mathrm{T}}$ at $15^{\circ} \mathrm{C}$.

\begin{tabular}{|lcr|}
\hline Fatty acid & WP2 $^{\mathbf{T}}$ & $\mathbf{W P 3}^{\mathbf{T}}$ \\
\hline $12: 0$ & 5.9 & 2.6 \\
iso- $13: 0$ & 7.3 & 8.0 \\
$13: 0$ & - & 0.6 \\
$3-\mathrm{OH} 12: 0$ & - & 0.6 \\
$14: 0$ & 7.9 & 2.6 \\
iso- $13: 03-\mathrm{OH}$ & 1.8 & 1.4 \\
iso- $15: 0$ & 4.0 & 10.3 \\
anteiso- $15: 0$ & - & 0.4 \\
$15: 0$ & - & 3.0 \\
$16: 1 \omega 7 c$ & 38.2 & 23.5 \\
$16: 0$ & 12.7 & 10.0 \\
$17: 1 \omega 8 c$ & 1.6 & 5.6 \\
$17: 0$ & - & 2.2 \\
$18: 1 \omega 7 c$ & - & 2.5 \\
$18: 1 \omega 7 t$ & 9.4 & 9.3 \\
$18: 0$ & 2.0 & 1.7 \\
$20: 5 \omega 3$ & 7.1 & 13.4 \\
\hline
\end{tabular}


PCR was used to amplify a portion of the $\operatorname{gyrB}$ gene according to the procedure of Yamamoto \& Harayama (1995). PCR products of $1200 \mathrm{bp}$ of the gyrB gene fragment (positions 274-1525 according to the Escherichia coli numbering scheme) were cloned into the pGEM-T vector by using a $2 \times$ rapid ligation kit according to the instructions of the manufacturer (Promega). Ligation mixtures were used to transform competent cells of E. coli XL1 Blue according to the manufacturer's recommendations (Promega). Positive clones were picked for sequencing (Sangon). The resulting sequences were searched in the NCBI database. Related sequences were aligned using the program DNAMAN (Lynnon Biosoft, v. 5.1). A phylogenetic tree was constructed from a matrix of pairwise genetic distances by the maximum-parsimony algorithm (Fitch, 1971) and the neighbour-joining method (Saitou \& Nei, 1987) using the DNAMAN program, and bootstrap analyses (1000 trials) were used to provide estimates of confidence for phylogenetic tree topologies.

The gyrB gene sequences of strains $\mathrm{WP}^{\mathrm{T}}$ and $\mathrm{WP} 3^{\mathrm{T}}$ shared $84 \%$ similarity. Strain $\mathrm{WP}^{\mathrm{T}}$ showed highest gyrB gene sequence similarity with the type strains of S. violacea $(90 \%)$ and S. benthica $(89 \%)$, and strain $\mathrm{WP}^{\mathrm{T}}$ showed highest similarity with the type strain of Shewanella sairae (87\%). The phylogenetic relationship of strains $\mathrm{WP}^{\mathrm{T}}$ and $\mathrm{WP}^{\mathrm{T}}$ with other Shewanella species based on gyrB gene sequences is shown in Fig. 3(b). Strain $\mathrm{WP}^{\mathrm{T}}$ clustered with $S$. violacea and S. benthica whereas strain $\mathrm{WP} 3^{\mathrm{T}}$ clustered with S. fidelis and S. sairea. This is not consistent with the results based on 16S rRNA gene sequence analyses (Fig. 3a; Wang et al., 2004).

Levels of DNA-DNA relatedness were determined by DNADNA slot-blot hybridization as described by Chen et al. (2005). Triplicate target DNA (50-200 ng) was denatured in $0.4 \mathrm{M} \mathrm{NaOH}$ and transferred onto a nylon membrane (Amersham, Pharmacia) and hybridized with sheared probes labelled with digoxin (DIG High Prime DNA Labeling and Detection Starter KitII; Roche). Hybridization was performed at $55{ }^{\circ} \mathrm{C}$, and high-stringency washes and signal detection were performed according to the manufacturer's instructions. Intensities of the signals were analysed using the GelBase/GelBlot-Pro software system. Signals produced by hybridization of the probe with homologous target DNA were considered to represent $100 \%$ hybridization. Levels of DNA-DNA hybridization between strains $\mathrm{WP} 2^{\mathrm{T}}$ and $\mathrm{WP} 3^{\mathrm{T}}$ and recognized Shewanella species are given in Table 3. Levels ranged from $60 \%$ $\left(\mathrm{WP}^{\mathrm{T}} /\right.$ S. benthica) to $19 \%\left(\mathrm{WP}^{\mathrm{T}} /\right.$ S. benthica) (Table 3), well below the $70 \%$ threshold used to define a genomic species (Wayne et al., 1987).

The use of gyrB sequences for phylogenetic placement of bacterial strains is well established (Yamamoto \& Harayama, 1995; Venkateswaran et al., 1999). The more rapid evolution of the $g y r B$ gene compared with that of the 16S rRNA gene makes it a more appropriate choice for differentiating between closely related strains. The $16 \mathrm{~S}$ rRNA gene sequence (a)
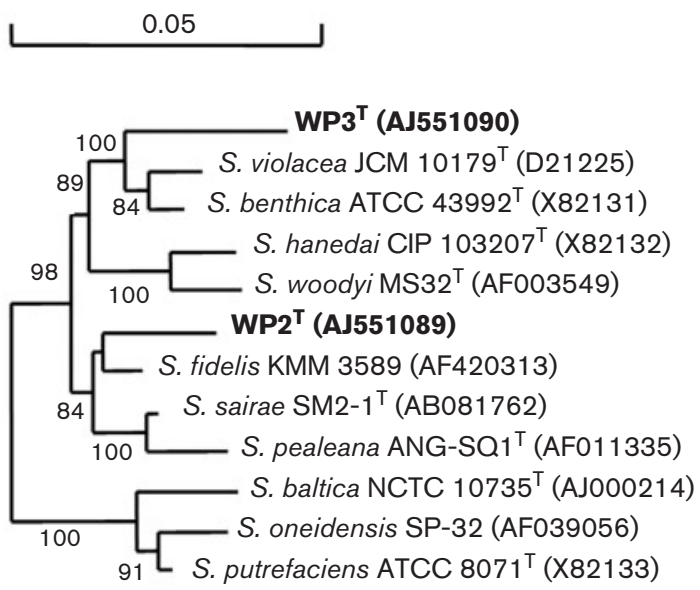

(b)
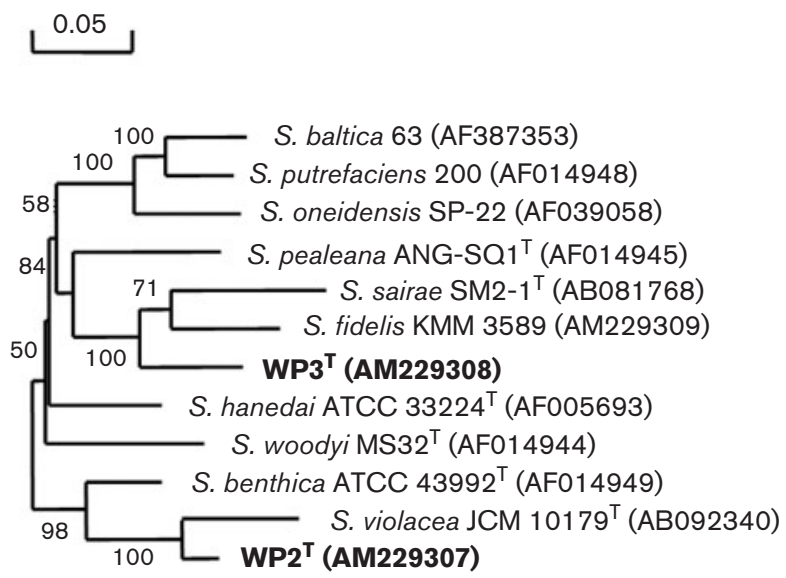

Fig. 3. Phylogenetic trees showing the relationships of strains ${ }_{W P 2}{ }^{\top}$ and $\mathrm{WP}^{\top}$ with other related Shewanella reference species based on 16S rRNA (a) and gyrB (b) gene sequences. Numbers at nodes are percentage bootstrap values based on 1000 trials. Bars, $0.05 \%$ sequence divergence.

of strain WP2 $2^{\mathrm{T}}$ had highest similarity (97\%) with S. fidelis KMM 3589, and strain WP3 ${ }^{\mathrm{T}}$ highest similarity (97\%) with S. benthica ATCC $43992^{\mathrm{T}}$. By contrast, the gyrB gene sequence of strain $\mathrm{WP} 2^{\mathrm{T}}$ exhibited highest similarity with those of the type strains of S. violacea and S. benthica ( 90 and $89 \%$, respectively), and the gyrB gene sequence of strain $\mathrm{WP} 3^{\mathrm{T}}$ exhibited highest similarity with that of the type strain of S. sairea (87\%). Discrepancies between gyrB and $16 \mathrm{~S}$ rRNA gene sequences were previously evident among the Shewanella species examined by Venkateswaran et al. (1999). DNA-DNA hybridization results indicated that strain $\mathrm{WP}^{\mathrm{T}}$ is most closely related to S. benthica. DNADNA hybridization and $g y r B$ sequence analysis both placed strain $\mathrm{WP}^{\mathrm{T}}$, S. violacea and S. benthica within a single phylogenetic clade. The results of the polyphasic taxonomic investigations performed in this study suggest that strains $\mathrm{WP} 2^{\mathrm{T}}$ and $\mathrm{WP}^{\mathrm{T}}$ represent two novel Shewanella species. The names Shewanella psychrophila sp. nov. and Shewanella 
Table 3. Levels of DNA-DNA relatedness between strains $\mathrm{WP}^{\top}$ and $\mathrm{WP}^{\top}$ and related Shewanella species $\mathrm{ND}$, Not determined. Values in parentheses are SD of three experiments.

\begin{tabular}{|c|c|c|c|c|}
\hline \multirow[t]{2}{*}{ Strain } & \multicolumn{4}{|c|}{ Hybridization (\%) with labelled DNA from: } \\
\hline & 1 & 2 & 3 & 4 \\
\hline 1. $\mathrm{WP} 2^{\mathrm{T}}$ & 100 & $24( \pm 2.02)$ & $55( \pm 1.99)$ & $38( \pm 2.27)$ \\
\hline 2. $\mathrm{WP}^{\mathrm{T}}$ & $29( \pm 1.91)$ & 100 & $38( \pm 3.74)$ & $33( \pm 5.08)$ \\
\hline 3. S. benthica ATCC $43992^{\mathrm{T}}$ & $60( \pm 1.52)$ & $19( \pm 5.36)$ & 100 & $46.4( \pm 4.69)$ \\
\hline 4. S. violacea JCM $10179^{\mathrm{T}}$ & $41( \pm 3.00)$ & $40( \pm 4.28)$ & $48.8( \pm 3.58)$ & 100 \\
\hline S. fidelis KMM 3589 & $32( \pm 3.64)$ & $38( \pm 5.11)$ & $\mathrm{ND}$ & ND \\
\hline
\end{tabular}

piezotolerans sp. nov. are proposed for strains $\mathrm{WP}^{\mathrm{T}}$ and $\mathrm{WP}^{\mathrm{T}}$, respectively.

\section{Description of Shewanella psychrophila sp. nov.}

Shewanella psychrophila (psy.chro' phi.la. Gr. adj. psychros cold; Gr. adj. philos loving; N.L. fem. adj. psychrophila cold loving).

Cells are Gram-negative rods that are $0.5-0.8 \mu \mathrm{m}$ wide and 2-5 $\mu \mathrm{m}$ long when grown at $0.1 \mathrm{MPa}$. Motile by means of a single polar flagellum. Facultatively anaerobic, with nitrate, TMAO and DMSO as electron acceptors. Colonies on agar plates are circular with a round edge and pale-yellow in colour. Growth occurs within the temperature range $0-20{ }^{\circ} \mathrm{C}$, with optimal growth at $10-15^{\circ} \mathrm{C}$. Growth occurs within the pressure range $0.1-50 \mathrm{MPa}$, with optimal growth at $20 \mathrm{MPa}$. Growth occurs at $\mathrm{NaCl}$ concentrations between 1 and $7.2 \%$ (optimum at 3-4\%), and at pH 6-8 (optimum at $\mathrm{pH} 7$ ). Positive for oxidase and catalase. Hydrogen sulfide is not produced. The following compounds are utilized for respiration (Biolog): Tweens 40 and 80, N-acetyl-Dglucosamine, myo-inositol, maltose, sucrose, D-trehalose, cis-aconitic acid, $\alpha$-ketovaleric acid, bromosuccinic acid, succinamic acid, L-alaninamide, D-alanine, L-glutamic acid, glycyl L-glutamic acid, L-histidine, hydroxy-L-proline, Lleucine, D-serine L-serine, L-threonine, DL-carnitine, thymidine and DL- $\alpha$-glycerol phosphate. Produces EPA. Major quinones are Q7 and Q8; MK7 and MMK7 are also present. The $\mathrm{G}+\mathrm{C}$ content of the DNA is $51 \mathrm{~mol} \%$.

The type strain, $\mathrm{WP} 2^{\mathrm{T}}\left(=\mathrm{JCM} 13876^{\mathrm{T}}=\mathrm{CGMCC} 1.6159^{\mathrm{T}}\right.$ ), was isolated from west Pacific deep-sea sediment.

\section{Description of Shewanella piezotolerans sp. nov.}

Shewanella piezotolerans (pie.zo'to.le.rans. Gr. v. piezo to press; L. part. adj. tolerans tolerating; N.L. fem. part. adj. piezotolerans pressure tolerating).

Cells are Gram-negative rods, $0.5-0.8 \mu \mathrm{m}$ wide and $2-5 \mu \mathrm{m}$ long, and motile by means of a single polar flagellum. Facultatively anaerobic, with nitrate, fumarate, TMAO, DMSO and insoluble Fe(III) as terminal electron acceptors. Grows at temperatures of $0-28{ }^{\circ} \mathrm{C}$, with optimal growth occurring at $15-20{ }^{\circ} \mathrm{C}$. Growth occurs within the pressure range $0.1-50 \mathrm{MPa}$, with optimal growth at $20 \mathrm{MPa}$. Growth occurs at $\mathrm{NaCl}$ concentrations between 1 and $7.2 \%$ (optimum at 3-4\%), and at $\mathrm{pH}$ 6-8 (optimum at $\mathrm{pH} 7$ ). Lipase, oxidase, catalase, gelatinase and amylase are produced. Hydrogen sulfide is produced from thiosulfate. Cells are able to reduce nitrate to nitrite. The following carbon sources are used: $\alpha$-cyclodextrin, dextrin, Tweens 40 and $80, N$-acetyl-D-glucosamine, gentiobiose, $\alpha$-D-glucose, maltose, acetic acid, DL-lactic acid, propionic acid, L-alanine, L-alanyl glycine, L-asparagine, L-glutamic acid, glycyl L-aspartic acid, glycyl L-glutamic acid, L-leucine, L-serine, L-threonine, inosine, uridine and thymidine. Produces EPA. Major quinones are Q7 and Q8; MK7 and MMK7 are also present. The $\mathrm{G}+\mathrm{C}$ content of the DNA is $49 \mathrm{~mol} \%$.

The type strain, $\mathrm{WP}^{\mathrm{T}}\left(=\mathrm{JCM} 13877^{\mathrm{T}}=\mathrm{CGMCC} 1.6160^{\mathrm{T}}\right)$, was isolated from west Pacific deep-sea sediment.

\section{Acknowledgements}

We are grateful to the crew of the DaYang No.1 for assistance in the collection of the samples. This work was partly supported by the COMRA foundation (DY105-4-2-7, DY105-2-04-02) and the Natural Science Foundation (40476001). D. H. B. is grateful to the National Science Foundation for support.

\section{References}

Bozal, N., Montes, M. J., Tudela, E., Jiménez, F. \& Guinea, J. (2002). Shewanella frigidimarina and Shewanella livingstonensis sp. nov. isolated from Antarctic coastal areas. Int J Syst Evol Microbiol 52, 195-205.

Chen, M., Xiao, X., Wang, P., Zeng, X. \& Wang, F. (2005). Arthrobacter ardleyensis sp. nov., isolated from Antarctic lake sediment and deep-sea sediment. Arch Microbiol 183, 301-305.

Collins, M. D., Pirouz, T., Goodfellow, M. \& Minnikin, D. E. (1977). Distribution of menaquinones in Actinomycetes and Corynebacteria. J Gen Microbiol 100, 221-230.

Deming, J. W., Hada, H., Colwell, R. R., Luehrsen, K. R. \& Fox, G. E. (1984). The ribonucleotide sequence of $5 S$ rRNA from two strains of deep-sea barophilic bacteria. J Gen Microbiol 130, 1911-1920.

Dong, X. Z. \& Cai, M. Y. (2001). Manual of Systematic Identification of Familiar Bacteria, 1st edn. Beijing: Science Publishing Company. 
Fitch, W. M. (1971). Toward defining the course of evolution: minimum change for a specific tree topology. Syst Zool 20, 406-416.

Kato, C. (1999). Barophiles (piezophiles). In Extremophiles in DeepSea Environments, pp. 91-111. Edited by K. Horikoshi \& K. Tsujii. Tokyo: Springer.

Kato, C. \& Nogi, Y. (2001). Correlation between phylogenetic structure and function: examples from deep-sea Shewanella. FEMS Microbiol Ecol 35, 223-230.

Li, S., Xiao, X., Li, J., Luo, J. \& Wang, F. (2006). Identification of genes regulated by changing salinity in the deep-sea bacterium Shewanella sp. WP3 using RNA arbitrarily primed PCR. Extremophiles 10, 97-104.

MacDonell, M. T. \& Colwell, R. R. (1985). Phylogeny of the Vibrionaceae, and recommendation for two genera, Listonella and Shewanella. Syst Appl Microbiol 6, 171-182.

Mesbah, M., Premachandran, U. \& Whitman, W. B. (1989). Precise measurement of the $\mathrm{G}+\mathrm{C}$ content of deoxyribonucleic acid by highperformance liquid chromatography. Int J Syst Bacteriol 39, 159-167.

Nishijima, M., Araki-Sakai, M. \& Sano, H. (1997). Identification of isoprenoid quinones by frit-FAB liquid chromatography-mass spectrometry for the chemotaxonomy of microorganisms. Methods Microbiol 28, 113-122.

Nogi, Y., Kato, C. \& Horikoshi, K. (1998). Taxonomic studies of deep-sea barophilic Shewanella strains and description of Shewanella violacea sp. nov. Arch Microbiol 170, 331-338.

Saitou, N. \& Nei, M. (1987). The neighbor-joining method: a new method for reconstructing phylogenetic trees. Mol Biol Evol 4, 406-425.

Satomi, M., Oikawa, H. \& Yano, Y. (2003). Shewanella marinintestina sp. nov., Shewanella schlegeliana sp. nov. and Shewanella sairae sp. nov., novel eicosapentaenoic-acid-producing marine bacteria isolated from sea-animal intestines. Int J Syst Evol Microbiol 53, 491-499.

Schleifer, K. H. \& Kandler, O. (1972). Peptidoglycan types of bacterial cell walls and their taxonomic implications. Bacteriol Rev 36, 407-477.
Skerratt, J. H., Bowman, J. P. \& Nichols, P. D. (2002). Shewanella olleyana sp. nov., a marine species isolated from a temperate estuary which produces high levels of polyunsaturated fatty acids. Int J Syst Evol Microbiol 52, 2101-2106.

Tamaoka, J. \& Komagata, K. (1984). Determination of DNA base composition by reversed-phase high-performance liquid chromatography. FEMS Microbiol Lett 25, 125-128.

Toffin, L., Bidault, A., Pignet, P., Tindall, B. J., Slobodkin, A., Kato, C. \& Prieur, D. (2004). Shewanella profunda sp. nov., isolated from deep marine sediment of the Nankai Trough. Int J Syst Evol Microbiol 54, 1943-1949.

Venkateswaran, K., Dollhopf, M. E., Aller, R., Stackebrandt, E. \& Nealson, K. H. (1998). Shewanella amazonensis sp. nov., a novel metal-reducing facultative anaerobe from Amazonian shelf muds. Int J Syst Bacteriol 48, 965-972.

Venkateswaran, K., Moser, D. P., Dollhopf, M. E., Lies, D. P., Saffarini, D. A., MacGregor, B. J., Ringelberg, D. B., White, D. C., Nishijima, M. \& other authors (1999). Polyphasic taxonomy of the genus Shewanella and description of Shewanella oneidensis sp. nov. Int J Syst Bacteriol 49, 705-724.

Wang, F. P., Wang, P., Chen, M. \& Xiao, X. (2004). Isolation of extremophiles with the detection and retrieval of Shewanella strains in deep-sea sediments from the west Pacific. Extremophiles 8, $165-168$.

Wayne, L. G., Brenner, D. J., Colwell, R. R., Grimont, P. A. D., Kandler, O., Krichevsky, M. I., Moore, L. H., Moore, W. E. C., Murray, R. G. E. \& other authors (1987). Report of the ad hoc committee on reconciliation of approaches to bacterial systematics. Int $J$ Syst Bacteriol 37, 463-464.

Yamamoto, S. \& Harayama, S. (1995). PCR amplification and direct sequencing of $g y r B$ genes with universal primers and their application to the detection and taxonomic analysis of Pseudomonas putida strains. Appl Environ Microbiol 61, 1104-1109.

Yayanos, A. A. \& Dietz, A. S. (1982). Coupling device for quick highpressure connections to $100 \mathrm{MPa}$. Rev Sci Instrum 53, 704-705. 